\title{
Appropriateness of Ticagrelor Use at Initiation: A Population-Based Cohort Study
}

\author{
Jean-Pierre Grégoire ${ }^{1,2}$, Paul Poirier ${ }^{1,3}$, Norma Pérez ${ }^{2}$, Éric Demers ${ }^{2}$, Jocelyne Moisan ${ }^{1,2}$ \\ ${ }^{1}$ Faculty of Pharmacy, Université Laval, Quebec City, QC, Canada; ${ }^{2}$ Population Health and Optimal Health Practices \\ Research Unit, CHU de Québec-Université Laval Research Centre, Quebec City, QC, Canada; ${ }^{3}$ Quebec Heart and Lung \\ Institute, Quebec City, QC, Canada.
}

Received, October 16, 2018; Accepted, October 28; Published, October 29, 2018.

\begin{abstract}
Purpose. Ticagrelor is recommended following an acute coronary syndrome if used appropriately. Its use has not yet been well described in the context of ambulatory clinical practice. The objective of this study was to assess the proportion of ticagrelor new users who initiated this medication appropriately and explore associated factors. Methods. A retrospective population-based inception cohort study was conducted using Quebec administrative databases. The study population included all Quebec residents aged $\geq 18$ years who had a first ticagrelor prescription claim between 1 January, 2012, and 31 March, 2015, and had been continuously eligible in the Quebec public drug plan during the 365 days preceding the first ticagrelor claim. The initial ticagrelor prescription was considered appropriate if:1) it met the indication for use criterion, 2) the prescribed daily dose was $90 \mathrm{mg}$ twice a day, and 3) there was a concomitant use of acetylsalicylic acid (ASA) 80-81 mg daily. Factors potentially associated with the ticagrelor appropriateness of use were included in a logistic log-binomial regression model. Results. A total of 7,073 patients were included in the study, 6,013 (85.0\%) had an appropriate indication, 6,895 (97.5\%) were prescribed ticagrelor $90 \mathrm{mg}$ twice a day, and 6,385 (90.3\%) had a concomitant prescription of ASA. A total of 5,371 (75.9\%) patients were prescribed ticagrelor in accordance with all criteria. Twelve factors were associated with prescription appropriateness. Conclusions. A large majority of patients initiated ticagrelor appropriately. Further improvement in appropriateness may come at targeting indication for use.
\end{abstract}

\section{INTRODUCTION}

Acute coronary syndrome (ACS) includes unstable angina (UA), non-ST-segment elevation myocardial infarction (NSTEMI), and ST-segment elevation myocardial infarction (STEMI). ${ }^{1}$ Secondary prevention medication is critical regarding the reduction of cardiovascular adverse events and death in the years following an ACS. Since 2011, the antiplatelet drug ticagrelor has been available in Canada. When co-administered with low doses of acetylsalicylic acid (ASA), this selective adenosine diphosphate receptor antagonist is indicated in the secondary prevention of ACS. ${ }^{2}$ In 2013, the Canadian Cardiovascular Society (CCS) updated guidelines regarding the use of antiplatelet therapy, including the use of ticagrelor. $^{3}$

The prescription of adenosine diphosphate receptor antagonists including ticagrelor has been assessed using selected data from hospital settings. ${ }^{4567}$ However, to our knowledge it has not yet been well described in the context of an ambulatory clinical practice using populationbased data. In addition, factors associated with the appropriate use of ticagrelor remain unstudied. As ticagrelor has been available for reimbursement through the province of Quebec public drug plan since February 2012, data from the Quebec Health
Insurance Board (RAMQ) provided the opportunity to evaluate the ambulatory use of ticagrelor within the drug plan. This medicoadministrative study was conducted to assess the proportion of ticagrelor new users who appropriately initiated this drug, and to explore factors associated with appropriate use.

\section{METHODS}

\section{Study Design and Data Source}

This retrospective population-based inception cohort study was conducted using databases from the RAMQ and the Quebec registry of hospitalizations. These databases include information on patient demographics, hospitalization, and physician services pertaining to all permanent residents of the province of Quebec. The RAMQ pharmaceutical services database also contains information on prescription drugs for all beneficiaries of the provincial public

Corresponding author: Jean-Pierre Grégoire, Population Health and Optimal Health Practices Research Unit, Centre de recherche du CHU de Québec-Université Laval, 1050, Chemin Sainte-Foy, Québec, QC, Canada, G1S 4L8. E-mail: jean-pierre.gregoire@pha.ulaval.ca 
drug plan (Quebec residents who are not eligible for a private drug insurance plan, welfare recipients, and people aged $\geq 65$ years).

\section{Population}

All Quebec residents aged $\geq 18$ years who had at least one claim of ticagrelor in the RAMQ pharmaceutical services database between 1 January, 2012, and 31 March, 2015 were included. They also had to have continuous eligibility in the Quebec public drug plan during the 365 days preceding their first ticagrelor claim.

\section{Variables}

The appropriateness of the first ticagrelor prescription claimed was evaluated considering 3 criteria based on the CCS updated guidelines regarding the use of antiplatelet therapy: $\left.{ }^{3} \quad 1\right)$ indication for use, 2) ticagrelor daily dose, and 3) concomitant prescription of ASA 80-81 mg daily. A patient was considered to have an appropriate indication if in the 365 days before or at the date of the first ticagrelor claim there was a diagnosis of ACS with either percutaneous coronary intervention (PCI) or coronary artery bypass grafting $(\mathrm{CABG})$. An ACS diagnosis without PCI or CABG was also considered appropriate if the patient was $\geq 60$ years or had an ischemic stroke, diabetes, peripheral arterial disease, or chronic renal dysfunction. ${ }^{3}$ A ticagrelor daily dose was considered appropriate if it was $90 \mathrm{mg}$ twice daily, and a patient was considered to be taking concomitant ASA if dispensed enough units of ASA 80-81 mg to be covered at the date of the first ticagrelor claim. The ticagrelor and the ASA daily doses were assessed using the dosage, the quantity dispensed, and the number of days supplied.

An array of patient-related, health-related, and treatment-related characteristics were considered as factors potentially associated with the ticagrelor appropriateness of use. Patientrelated characteristics were assessed at the date of the first ticagrelor claim. They included age, sex and socioeconomic status (no/partial/maximum guaranteed income supplement). The following health-related characteristics were assessed in the year before the first ticagrelor claim (date of first ticagrelor claim included) using physician services or hospital data: presence of cardiac-related diseases and other comorbidities (diabetes, hypertension, dyslipidemia, ischemic stroke, peripheral arterial disease), chronic renal dysfunction, upper gastro-intestinal bleeding, and diseases that may reduce life expectancy (dementia, non-skin neoplasia). As for the treatment-related characteristics, the specialty of the physician who initially prescribed ticagrelor and the calendar year of treatment initiation were assessed. Health services characteristics were also assessed in the year preceding the date (included) of the first ticagrelor claim: total number of days of hospitalization; total number of physician visits; visits to a general practitioner (yes/no) and to a cardiologist (yes/no); cardiac revascularization procedures (CABG, $\mathrm{PCI}$ ); and drugs (number of distinct drugs claimed, cardiovascular drugs).

\section{STATISTICAL ANALYSIS}

The proportion of patients who used ticagrelor appropriately was calculated. Patient characteristics were assessed using descriptive statistics. Factors that were potentially associated with appropriate prescription were explored using a multivariable log-binomial regression model. Using the stepwise procedure, all variables with a $P$-value $<0.05$ were kept in the model. Adjusted prevalence ratios (PR) with $95 \%$ confidence intervals (CIs) were calculated. Factors were considered to be associated with the appropriateness of ticagrelor use if the adjusted PR was statistically significant, i.e. if the $95 \%$ CI did not include the ' 1 ' value (alternatively if the Pvalue was $<0.05$ ). There was no issue of multicollinearity, which was assessed using a multiple regression analysis. Analyses were performed using SAS, version 9.4 (SAS Institute, Inc., Cary, NC).

\section{Ethics}

The study research protocol was approved by the Research Ethics Committee of the CHU de Québec-Université Laval Hospital.

\section{RESULTS}

A total of 7,073 patients undertaking a ticagrelor regimen constituted the study population. Of these patients, $6,013(85.0 \%)$ had an appropriate indication, 6,895 (97.5\%) were prescribed ticagrelor $90 \mathrm{mg}$ twice a day, and 6,385 (90.3\%) had a concomitant prescription of ASA at a dosage of $80-81 \mathrm{mg}$ (Table 1). A total of $190(2.7 \%)$ patients had no ASA claim. In all, 5,371 (75.9\%) individuals initiated ticagrelor appropriately, i.e. in accordance with all of the aforementioned criteria. The mean (standard deviation) age of the patients was $67.8(10.7)$ years, with 5,585 (78.9\%) patients aged $\geq 60$ years. A total of $4,738(67.0 \%)$ patients were men. A high proportion of patients had cardiovascular comorbidities and used cardiovascular drugs. Only 315 (4.5\%) had not been hospitalized in the 365-day period preceding their first ticagrelor claim. A total of 1,203 (17.0\%) patients had previously used clopidogrel or prasugrel. 
Table 1. Ticagrelor appropriate prescription in patients who initiated this drug between January 1, 2012 and March $31,2015(n=7,073)$

\begin{tabular}{|c|c|c|}
\hline Criteria for ticagrelor appropriate prescription & $n$ & $\%$ \\
\hline \multicolumn{3}{|l|}{ Appropriate indication } \\
\hline Yes & 6,013 & 85.0 \\
\hline No & 1060 & 15.0 \\
\hline $\begin{array}{l}\left(\mathrm{ACS}^{\mathrm{a}} \text { without } \mathrm{PCI}^{\mathrm{b}} \text { or } \mathrm{CABG} \mathrm{C}^{\mathrm{c}} \text { and without age } \geq 60 \text { years, ischemic stroke, }\right. \\
\text { diabetes, peripheral arterial disease or chronic renal dysfunction) }\end{array}$ & $(153)$ & $(14.4)^{*}$ \\
\hline (No ACS) & $(907)$ & $(85.6)^{*}$ \\
\hline \multicolumn{3}{|l|}{ Dosage of the first ticagrelor claim $=90 \mathrm{mg}$ twice a day } \\
\hline Yes & 6,895 & 97.5 \\
\hline No & 178 & 2.5 \\
\hline (Dosage $>90 \mathrm{mg}$ twice a day) & $(87)$ & $(48.9)^{*}$ \\
\hline (Dosage $<90 \mathrm{mg}$ twice a day) & (91) & $(51.1)^{*}$ \\
\hline \multicolumn{3}{|l|}{ Concomitant prescription of $\mathrm{ASA}^{\mathrm{d}} 80-81 \mathrm{mg}$} \\
\hline Yes & 6,385 & 90.3 \\
\hline No & 688 & 9.7 \\
\hline Had a dosage of ASA $\neq 80-81 \mathrm{mg}$ & $(498)$ & $(72.4)^{*}$ \\
\hline Had no ASA & $(190)$ & $(27.6) *$ \\
\hline \multicolumn{3}{|l|}{ Appropriate prescription (met all criteria) } \\
\hline Yes & 5,371 & 75.9 \\
\hline No & 1,702 & 24.1 \\
\hline No recommended indication & $(904)$ & $(53.1)^{*}$ \\
\hline Dosage of the first ticagrelor claim $\neq 90 \mathrm{mg}$ twice a day & $(93)$ & $(5.5)^{*}$ \\
\hline No ASA $80-81 \mathrm{mg}$ & $(488)$ & $(28,7)^{*}$ \\
\hline No indication and dosage of the first ticagrelor claim $\neq 90 \mathrm{mg}$ twice a day & $(17)$ & $(1,0) *$ \\
\hline No indication and no ASA $80-81 \mathrm{mg}$ & $(132)$ & $(7,7)^{*}$ \\
\hline Dosage of the first ticagrelor claim $\neq 90 \mathrm{mg}$ twice a day and no ASA $80-81 \mathrm{mg}$ & $(61)$ & $(3,6)^{*}$ \\
\hline $\begin{array}{l}\text { No indication, dosage of the first ticagrelor claim } \neq 90 \mathrm{mg} \text { twice a day and no } \\
\text { ASA } 80-81 \mathrm{mg}\end{array}$ & (7) & $(0.4)^{*}$ \\
\hline $\begin{array}{l}\text { * Denominator: number of patients whose ticagrelor prescription did not meet the criterio } \\
\text { a ACS: acute coronary syndrome } \\
\text { b PCI: percutaneous coronary intervention } \\
{ }^{\text {c }} \text { CABG: coronary artery bypass grafting } \\
\text { d ASA: acetylsalicylic acid }\end{array}$ & & \\
\hline
\end{tabular}

A total of 12 factors were kept in the final multivariable model. All 12 factors were statistically associated with the appropriate initial use of ticagrelor (Table 2). Patients with prior cardiac dysrhythmia, chronic renal dysfunction, dyslipidemia and hypertension, as well as those who, in the year prior to the initiation of ticagrelor, visited a general practitioner, took a statin or fibrate, and took antihypertensive agents, were more likely to initiate ticagrelor appropriately. On the other hand, the likelihood to use ticagrelor appropriately was reduced among patients who had atrial fibrillation, cardiomyopathy and dyspnea, those who had made more than 6 visits to a physician, and those who had used clopidogrel or prasugrel in the year before initiating ticagrelor.

\section{DISCUSSION}

One principal finding emerges from this study. Three out of four individuals initiated ticagrelor according to all criteria of appropriateness. Noteworthy, the proportion of appropriate use with regard to the concomitant use of ASA $80-81 \mathrm{mg}$ was very high $(90.3 \%)$.

The proportion of appropriateness of use varied according to each of the 3 criteria. The high proportion $(85.0 \%)$ of appropriateness on indication for use suggests that physicians might have been aware either of the CCS guidelines ${ }^{3}$ on that criterion or of the $\mathrm{PLATO}^{8}$ study inclusion criteria on which the CCS guidelines are based. This proportion is higher than the one observed in a registry study including 227 patients who started ticagrelor at a PCI facility in Saskatchewan. ${ }^{4}$ In this latter study, only $67.6 \%$ of patients had met the indication criteria, which were similar to ours. As in the current study, a high proportion of individuals $(97.5 \%)$ were prescribed ticagrelor 90 mg twice daily, which illustrates a close-to-perfect adherence to the daily dose recommended in the CCS guidelines. ${ }^{3}$

Only $190(2.7 \%)$ individuals were not using ASA concomitantly with ticagrelor. Although low, this proportion may have been underestimated as some individuals may have bought their prescribed 
ASA over the counter, and therefore, those transactions were not captured in the RAMQ database. In an administrative database study conducted in Denmark including all patients hospitalized for a first myocardial infarction from 2009 through 2012, Green et al. ${ }^{6}$ observed that $100 \%$ of the 921 patients discharged with ticagrelor were prescribed ASA. In a study conducted in Sweden including patients hospitalized for ACS, $97.8 \%$ of patients discharged with ticagrelor were prescribed concomitant use of ASA. $^{7}$

Seven factors associated with ticagrelor appropriateness of use were health-related characteristics (atrial fibrillation, cardiac dysrhythmia, cardiomyopathy, chronic renal dysfunction, dyslipidemia, dyspnea, hypertension), while 5 were treatment-related characteristics (number of physician visits, visits to a general practitioner, prior use of clopidogrel or prasugrel, prior use of a statin or fibrate, and prior use of an antihypertensive drug). The clinical significance of observed associations is difficult to establish as most were weak in magnitude. They are also difficult to interpret in absence of clinical data not captured in the administrative databases. Results should therefore be considered for their exploratory value as they highlight some areas for future research aiming to optimize ticagrelor prescribing practices.

\section{LIMITATIONS}

This study has some limitations inherent to the use of administrative databases. First, because prescriptions issued by physicians are not captured in the databases, we were able to assess only prescriptions that were filled at the pharmacy. As mentioned above, ASA may have been prescribed to some patients who chose not to fill their prescription or bought it over the counter. However, the impact of this is likely to be minimal given only $2.7 \%$ of patients did not claim an ASA concomitantly to ticagrelor. Second, as it is not mandatory for physicians in Quebec to record all diagnoses when they claim to RAMQ an ambulatory service provided to patients, an unknown proportion of patients prescribed ticagrelor may have had an ACS but this diagnosis was not registered in the 365-day period preceding ticagrelor initiation. This could be the case for some of the 477 patients (data not shown) who had a PCI or a CABG and for whom there was no record of ACS. Therefore, the proportion of appropriate ticagrelor initial use may have been underestimated. Third, many clinical characteristics (ex.: bradycardia, shortness of breath, use of biomarkers) are not captured in the
RAMQ administrative database. Therefore, some cases not meeting criteria for appropriateness could have been judged as appropriate if an indepth assessment of the clinical situation would have been possible. Consequently, cases of nonappropriateness should be considered as "potentially" non-appropriate. Finally, it was not possible to explore some prescriber-related factors (knowledge and attitudes) that could be associated with the quality of prescribing since this information is not recorded.

\section{CONCLUSIONS}

In this study, the appropriateness of ticagrelor use at initiation of treatment was assessed in the context of ambulatory clinical practice. It had not yet been done using population-based data. Our results suggest that overall, this medication was appropriately used by a majority of patients. Identified associated factors might help better understand why some patients are potentially using ticagrelor non-appropriately.

\section{ACKNOWLEDGEMENTS}

This study was supported by a non-restricted grant from AstraZeneca Canada.

\section{ETHICAL APPROVAL}

This article does not contain any studies with human participants performed by any of the authors.

\section{REFERENCES}

1. Kumar A, Cannon CP. Acute coronary syndromes: diagnosis and management, part I. Mayo Clin Proc. 2009;84(10):917-938.

DOI:10.1016/S00256196(11)60509-0.

2. Summary Basis of Decision (SBD) PrBRILINTA ${ }$, Ticagrelor, $90 \mathrm{mg}$ tablet, AstraZeneca Inc., Submission Control Number: 132218 Health Canada, 2011.

3. Tanguay JF, Bell AD, Ackman ML, et al. Focused 2012 update of the Canadian Cardiovascular Society guidelines for the use of antiplatelet therapy. Can J Cardiol. 2013;29(11):1334-1345. DOI:10.1016/j.cjca.2013.07.001.

4. Dehghani P, Chopra V, Bell A, et al. Southern Saskatchewan Ticagrelor Registry experience. Patient Prefer Adherence. 2014;8:1427-1435. DOI:10.2147/PPA.S68423.

5. Gandhi S, Zile B, Tan MK, et al. Increased uptake of guideline-recommended oral antiplatelet therapy: insights from the Canadian acute coronary syndrome reflective. Can J Cardiol. 2014;30(12):1725-1731. DOI:10.1016/j.cjca.2014.09.011. 
6. Green A, Pottegard A, Broe A, et al. Initiation and persistence with dual antiplatelet therapy after acute myocardial infarction: a Danish nationwide population-based cohort study. BMJ Open. 2016;6(5):e010880. DOI:10.1136/bmjopen-2015010880.

7. Sahlen A, Varenhorst C, Lagerqvist B, et al. Contemporary use of ticagrelor in patients with acute coronary syndrome: insights from Swedish Web System for Enhancement and Development of Evidence-Based Care in Heart Disease Evaluated According to Recommended Therapies (SWEDEHEART). Eur Heart J Cardiovasc Pharmacother. 2016;2(1):5-12. DOI:10.1093/ehjcvp/pvv034.

8. Wallentin L, Becker RC, Budaj A, et al. Ticagrelor versus clopidogrel in patients with acute coronary syndromes. N Engl J Med. 2009;361(11):10451057. DOI:10.1056/NEJMoa0904327. 
J Pharm Pharm Sci (www.cspsCanada.org) 22, 1 - 9, 2019

Table 2. Association between patient-related, health-related and treatment-related characteristics and ticagrelor appropriate prescription $(n=7,073)$

\begin{tabular}{|c|c|c|c|c|c|c|c|c|c|c|}
\hline \multirow[t]{3}{*}{ Characteristics } & \multicolumn{4}{|c|}{ Appropriate use } & \multirow{3}{*}{$\begin{array}{l}\text { Crude } \\
\text { Prevalence } \\
\text { Ratio (PR) }\end{array}$} & \multirow{3}{*}{$\begin{array}{l}95 \% \\
\text { Confidence } \\
\text { intervals }\end{array}$} & \multirow{3}{*}{$\begin{array}{l}P \\
\text { value }\end{array}$} & \multirow{3}{*}{$\begin{array}{l}\text { Adjusted } \\
\text { PR }\end{array}$} & \multirow{3}{*}{$\begin{array}{l}95 \% \\
\text { Confidence } \\
\text { intervals }\end{array}$} & \multirow{3}{*}{$\begin{array}{l}P \\
\text { value }\end{array}$} \\
\hline & \multicolumn{2}{|c|}{ Yes } & \multicolumn{2}{|c|}{ No } & & & & & & \\
\hline & $\begin{array}{c}n \\
5,371\end{array}$ & $\begin{array}{c}(\%) \\
(75.9)\end{array}$ & $\begin{array}{c}n \\
1,702\end{array}$ & $\begin{array}{c}(\%) \\
(24.1)\end{array}$ & & & & & & \\
\hline \multicolumn{11}{|l|}{ Patient-related } \\
\hline $\begin{array}{l}\text { Age, mean } \pm \text { standard } \\
\text { deviation }\end{array}$ & $67.8 \pm 10.7$ & & $67.6 \pm 10.7$ & & 1.00 & $0.99-1.01$ & 0.87 & & & \\
\hline \multicolumn{11}{|l|}{ Sex } \\
\hline Women & 1,761 & 32.8 & 574 & 33.7 & 1.00 & & & & & \\
\hline Men & 3,610 & 67.2 & 1128 & 66.3 & 1.01 & $0.98-1.04$ & 0.48 & & & \\
\hline \multicolumn{11}{|l|}{ Socioeconomic status } \\
\hline $\begin{array}{l}\text { No Guaranteed Income } \\
\text { Supplement (GIS) }\end{array}$ & 3,156 & 58.8 & 998 & 58.6 & 1.00 & & & & & \\
\hline Partial GIS & 1,553 & 28.9 & 480 & 28.2 & 1.01 & $0.98-1.04$ & 0.63 & & & \\
\hline $\begin{array}{l}\text { Welfare or maximum } \\
\text { GIS }\end{array}$ & 662 & 12.3 & 224 & 13.2 & 0.98 & $0.94-1.03$ & 0.72 & & & \\
\hline \multicolumn{11}{|l|}{$\begin{array}{l}\text { Calendar year at ticagrelor } \\
\text { initiation }\end{array}$} \\
\hline 2012 & 488 & 9.1 & 148 & 8.7 & 1.00 & & & & & \\
\hline 2013 & 1,805 & 33.6 & 596 & 35.0 & 0.98 & $0.93-1.03$ & 0.74 & & & \\
\hline 2014 & 2,417 & 45.0 & 756 & 44.4 & 0.99 & $0.95-1.04$ & 0.76 & & & \\
\hline 2015 & 661 & 12.3 & 202 & 11.8 & 1.00 & $0.94-1.06$ & 0.95 & & & \\
\hline \multicolumn{11}{|l|}{ Health-related } \\
\hline \multicolumn{11}{|l|}{$\overline{\text { Anemia }}$} \\
\hline No & 4,493 & 83.6 & 1,445 & 84.9 & 1.00 & $0.99-1.06$ & 0.21 & & & \\
\hline Yes & 878 & 16.4 & 257 & 15.1 & 1.02 & $0.99-1.06$ & 0.21 & & & \\
\hline \multicolumn{11}{|l|}{ Atrial fibrillation } \\
\hline No & 4,980 & 92.7 & 1,566 & 92.0 & 1.00 & & & Ref & & \\
\hline Yes & 391 & 7.3 & 136 & 8.0 & 0.98 & $0.93-1.03$ & 0.35 & 0.94 & $0.89-0.98$ & 0.01 \\
\hline \multicolumn{11}{|l|}{ Cardiac dysrhythmia } \\
\hline No & 3,831 & 71.3 & 1,290 & 75.8 & 1.00 & & & Ref & & \\
\hline Yes & 1,540 & 28.7 & 412 & 24.2 & 1.05 & $1.03-1.08$ & $<0.01$ & 1.07 & $1.04-1.10$ & $<0.01$ \\
\hline \multicolumn{11}{|l|}{ Cardiomyopathy } \\
\hline No & 5,243 & 97.6 & 1,634 & 96.0 & 1.00 & & & Ref & & \\
\hline Yes & 128 & 2.4 & 68 & 4.0 & 0.86 & $0.77-0.95$ & $<0.01$ & 0.89 & $0.80-0.98$ & 0.02 \\
\hline \multicolumn{11}{|l|}{ Chronic heart failure } \\
\hline No & 4,315 & 80.3 & 1,352 & 79.04 & 1.00 & & & & & \\
\hline Yes & 1,056 & 19.7 & 350 & 20.6 & 0.99 & $0.95-1.02$ & 0.42 & & & \\
\hline
\end{tabular}


J Pharm Pharm Sci (www.cspsCanada.org) 22, 1 - 9, 2018

\begin{tabular}{|c|c|c|c|c|c|c|c|c|c|c|}
\hline \multirow[t]{3}{*}{ Characteristics } & \multicolumn{4}{|c|}{ Appropriate use } & \multirow{3}{*}{$\begin{array}{l}\text { Crude } \\
\text { Prevalence } \\
\text { Ratio (PR) }\end{array}$} & \multirow{3}{*}{$\begin{array}{l}95 \% \\
\text { Confidence } \\
\text { intervals }\end{array}$} & \multirow{3}{*}{$\begin{array}{l}P \\
\text { value }\end{array}$} & \multirow{3}{*}{$\begin{array}{l}\text { Adjusted } \\
\text { PR }\end{array}$} & \multirow{3}{*}{$\begin{array}{l}95 \% \\
\text { Confidence } \\
\text { intervals }\end{array}$} & \multirow{3}{*}{$\begin{array}{l}P \\
\text { value }\end{array}$} \\
\hline & \multicolumn{2}{|c|}{ Yes } & \multicolumn{2}{|c|}{ No } & & & & & & \\
\hline & $\begin{array}{c}n \\
5,371 \\
\end{array}$ & $\begin{array}{c}(\%) \\
(75.9)\end{array}$ & $\begin{array}{c}n \\
1,702\end{array}$ & $\begin{array}{c}(\%) \\
(24.1)\end{array}$ & & & & & & \\
\hline \multicolumn{11}{|c|}{ Chronic renal dysfunction } \\
\hline No & 4,652 & 86.6 & 1,512 & 88.8 & 1.00 & & & Ref & & \\
\hline Yes & 719 & 13.4 & 190 & 11.2 & 1.05 & $1.01-1.09$ & 0.01 & 1.06 & $1.03-1.10$ & $<0.01$ \\
\hline \multicolumn{11}{|c|}{$\begin{array}{l}\text { Chronic obstructive } \\
\text { pulmonary disease }\end{array}$} \\
\hline No & 4,639 & 86.4 & 1,473 & 86.5 & 1.00 & & & & & \\
\hline Yes & 732 & 13.6 & 229 & 13.5 & 1.00 & $0.97-1.04$ & 0.85 & & & \\
\hline \multicolumn{11}{|c|}{ Deep venous thrombosis } \\
\hline No & 5,360 & 99.8 & 1,698 & 99.8 & 1.00 & & & & & \\
\hline Yes & 11 & 0.2 & 4 & 0.2 & 0.97 & $0.71-1.31$ & 0.82 & & & \\
\hline \multicolumn{11}{|l|}{ Dementia } \\
\hline No & 5,263 & 98.0 & 1,668 & 98.0 & 1.00 & & & & & \\
\hline Yes & 108 & 2.0 & 34 & 2.0 & 1.00 & $0.91-1.10$ & 0.97 & & & \\
\hline \multicolumn{11}{|l|}{ Diabetes } \\
\hline No & 3,638 & 67.7 & 1,144 & 67.2 & 1.00 & & & & & \\
\hline Yes & 1,733 & 32.3 & 558 & 32.8 & 0.99 & $0.97-1.02$ & 0.69 & & & \\
\hline \multicolumn{11}{|l|}{ Dyslipidemia } \\
\hline No & 1,603 & 29.9 & 692 & 40,7 & 1.00 & & & Ref & & \\
\hline Yes & 3,768 & 70.1 & 1110 & 59.3 & 1.13 & $1.10-1.16$ & $<0.01$ & 1.09 & $1.05-1.12$ & $<0.01$ \\
\hline \multicolumn{11}{|l|}{ Dyspnea } \\
\hline No & 4,718 & 87.8 & 1,411 & 82.9 & 1.00 & & & Ref & & \\
\hline Yes & 653 & 12.2 & 291 & 17.1 & 0.90 & $0.86-0.94$ & $<0.01$ & 0.93 & $0.89-0.97$ & $<0.01$ \\
\hline \multicolumn{11}{|l|}{ Hypertension } \\
\hline No & 1,763 & 32.8 & 660 & 38.8 & 1.00 & & & Ref & & \\
\hline Yes & 3,608 & 67.2 & 1042 & 61.2 & 1.07 & $1.04-1.10$ & $<0.01$ & 1.03 & $1.00-1.06$ & 0.04 \\
\hline \multicolumn{11}{|l|}{ Ischemic stroke } \\
\hline No & 5,121 & 95.3 & 1,608 & 94.5 & 1.00 & & & & & \\
\hline Yes & 250 & 4.7 & 94 & 5.5 & 0.95 & $0.89-1.02$ & 0.17 & & & \\
\hline \multicolumn{11}{|c|}{ Non-skin neoplasia } \\
\hline No & 4,514 & 84.0 & 1,425 & 83.7 & 1.00 & & & & & \\
\hline Yes & 857 & 16.0 & 277 & 16.3 & 0.99 & $0.96-1.03$ & 0.76 & & & \\
\hline \multicolumn{11}{|l|}{ Peptic ulcer } \\
\hline No & 5,324 & 99.1 & 1,677 & 98.5 & 1.00 & & & & & \\
\hline Yes & 47 & 0.9 & 25 & 1.5 & 0.86 & $0.72-1.02$ & 0.08 & & & \\
\hline
\end{tabular}


J Pharm Pharm Sci (www.cspsCanada.org) 22, 1 - 9, 2019

Table 2. Association between patient-related, health-related and treatment-related characteristics and ticagrelor appropriate prescription $(n=7,073)$

\begin{tabular}{|c|c|c|c|c|c|c|c|c|c|c|}
\hline \multirow[t]{3}{*}{ Characteristics } & \multicolumn{4}{|c|}{ Appropriate use } & \multirow{3}{*}{$\begin{array}{l}\text { Crude } \\
\text { Prevalence } \\
\text { Ratio (PR) }\end{array}$} & \multirow{3}{*}{$\begin{array}{l}95 \% \\
\text { Confidence } \\
\text { intervals }\end{array}$} & \multirow{3}{*}{$\begin{array}{l}P \\
\text { value }\end{array}$} & \multirow{3}{*}{$\begin{array}{l}\text { Adjusted } \\
\text { PR }\end{array}$} & \multirow{3}{*}{$\begin{array}{l}95 \% \\
\text { Confidence } \\
\text { intervals }\end{array}$} & \multirow{3}{*}{$\begin{array}{l}P \\
\text { value }\end{array}$} \\
\hline & \multicolumn{2}{|c|}{ Yes } & \multicolumn{2}{|c|}{ No } & & & & & & \\
\hline & $\begin{array}{c}n \\
5,371\end{array}$ & $\begin{array}{c}(\%) \\
(75.9)\end{array}$ & $\begin{array}{c}n \\
1,702\end{array}$ & $\begin{array}{c}(\%) \\
(24.1)\end{array}$ & & & & & & \\
\hline \multicolumn{11}{|l|}{ Peripheral arterial disease } \\
\hline No & 4,714 & 87.8 & 1,522 & 89.4 & 1.00 & & & & & \\
\hline Yes & 657 & 12.2 & 180 & 10.6 & 1.04 & $1.00-1.08$ & 0.05 & & & \\
\hline \multicolumn{11}{|l|}{$\begin{array}{l}\text { Upper gastrointestinal } \\
\text { bleeding }\end{array}$} \\
\hline No & 5,249 & 97,7 & 1,651 & 97.0 & 1.00 & & & & & \\
\hline Yes & 122 & 2.3 & 51 & 3.0 & 0.93 & $0.84-1.02$ & 0.13 & & & \\
\hline \multicolumn{11}{|l|}{ Treatment-related } \\
\hline \multicolumn{11}{|c|}{$\begin{array}{l}\text { Specialty of physician who } \\
\text { prescribed ticagrelor }\end{array}$} \\
\hline General practitioner & 2,034 & 37.9 & 548 & 32.2 & 1.00 & & & & & \\
\hline Cardiologist & 2,771 & 51.6 & 986 & 57.9 & 0.94 & $0.91-0.96$ & $<0.01$ & & & \\
\hline Internist & 450 & 8.4 & 124 & 7.3 & 1.00 & $0.95-1.04$ & 0.84 & & & \\
\hline Other or missing & 116 & 2.4 & 44 & 2.4 & 0.92 & $0.83-1.01$ & 0.10 & & & \\
\hline \multicolumn{11}{|c|}{ Number of physician visits } \\
\hline $1^{\text {st }}$ tertile $(0-5)$ & 1,828 & 34.0 & 414 & 24.3 & 1.00 & & & Ref & & \\
\hline $2^{\text {nd }}$ tertile $(6-10)$ & 1,820 & 33.9 & 602 & 35.4 & 0.92 & $0.89-0.95$ & $<0.01$ & 0.90 & $0.88-0.93$ & $<0.01$ \\
\hline $3^{\text {rd }}$ tertile $(11-224)$ & 1,723 & 32.1 & 686 & 40.3 & 0.88 & $0.85-0.91$ & $<0.01$ & 0.86 & $0.83-0.89$ & $<0.01$ \\
\hline \multicolumn{11}{|l|}{$\begin{array}{l}\text { Visits to a general } \\
\text { practitioner }\end{array}$} \\
\hline No & 193 & 3.6 & 158 & 9.3 & 1.00 & & & Ref & & \\
\hline Yes & 5,178 & 96.4 & 1,544 & 90.7 & 1.40 & $1.27-1.54$ & $<0.01$ & 1.41 & $1.29-1.56$ & $<0.01$ \\
\hline \multicolumn{11}{|l|}{ Visits to a cardiologist } \\
\hline No & 1,378 & 25.7 & 354 & 20.8 & 1.00 & & & & & \\
\hline Yes & 3,993 & 74.3 & 1,348 & 79.2 & 0.94 & $0.91-0.97$ & $<0.01$ & & & \\
\hline \multicolumn{11}{|l|}{ Use of an anticoagulant } \\
\hline No & 5,148 & 75.8 & 1,609 & 94.5 & 1.00 & & & & & \\
\hline Yes & 223 & 4.2 & 93 & 5.5 & 0.93 & $0.86-0.99$ & 0.04 & & & \\
\hline \multicolumn{11}{|l|}{$\begin{array}{l}\text { Use of clopidogrel or } \\
\text { prasugrel }\end{array}$} \\
\hline No & 4,513 & 84.0 & 1,357 & 79.7 & 1.00 & & & Ref & & \\
\hline Yes & 858 & 16.0 & 345 & 20.3 & 0.93 & $0.89-0.96$ & $<0.01$ & 0.95 & $0.92-0.99$ & 0.01 \\
\hline \multicolumn{11}{|l|}{ Use of statin or fibrate } \\
\hline No & 161 & 3.0 & 96 & 5.6 & 1.00 & & & Ref & & \\
\hline
\end{tabular}


J Pharm Pharm Sci (www.cspsCanada.org) 22, 1 - 9, 2018

\begin{tabular}{|c|c|c|c|c|c|c|c|c|c|c|}
\hline \multirow[t]{3}{*}{ Characteristics } & \multicolumn{4}{|c|}{ Appropriate use } & \multirow{3}{*}{$\begin{array}{l}\text { Crude } \\
\text { Prevalence } \\
\text { Ratio (PR) }\end{array}$} & \multirow{3}{*}{$\begin{array}{l}95 \% \\
\text { Confidence } \\
\text { intervals }\end{array}$} & \multirow{3}{*}{$\begin{array}{l}P \\
P \\
\text { value }\end{array}$} & \multirow{3}{*}{$\begin{array}{l}\text { Adjusted } \\
\text { PR }\end{array}$} & \multirow{3}{*}{$\begin{array}{l}95 \% \\
\text { Confidence } \\
\text { intervals }\end{array}$} & \multirow{3}{*}{$\begin{array}{l}P \\
\text { value }\end{array}$} \\
\hline & \multicolumn{2}{|c|}{ Yes } & \multicolumn{2}{|c|}{ No } & & & & & & \\
\hline & $\begin{array}{c}n \\
5,371 \\
\end{array}$ & $\begin{array}{c}(\%) \\
(75.9)\end{array}$ & $\begin{array}{c}n \\
1,702 \\
\end{array}$ & $\begin{array}{l}(\%) \\
(24.1)\end{array}$ & & & & & & \\
\hline Yes & 5,210 & 97.0 & 1,606 & 94.4 & 1.22 & $1.11-1.34$ & $<0.01$ & 1.14 & $1.04-1.25$ & 0.01 \\
\hline \multicolumn{11}{|c|}{$\begin{array}{l}\text { Use of an antihypertensive } \\
\text { drug }\end{array}$} \\
\hline No & 182 & 3.4 & 89 & 5.2 & 1.00 & & & Ref & & \\
\hline Yes & 5,189 & 96.6 & 1,613 & 94.8 & 1.14 & $1.04-1.24$ & $<0.01$ & 1.09 & $1.00-1.19$ & 0.03 \\
\hline \multicolumn{11}{|c|}{ Use of estrogen (in women) } \\
\hline No & 1,690 & 96.0 & 545 & 94.9 & 1.00 & & & & & \\
\hline Yes & 71 & 4.0 & 29 & 5.1 & 0.94 & $0.83-1.07$ & 0.33 & & & \\
\hline \multicolumn{11}{|c|}{ Use of an antidiabetes drug } \\
\hline No & 4,020 & 74.8 & 1,229 & 72.2 & 1.00 & & & & & \\
\hline Yes & 1,351 & 25.2 & 473 & 27.8 & 0.97 & 0.94-0.99 & 0.03 & & & \\
\hline \multicolumn{11}{|l|}{ Use of nitrates } \\
\hline No & 1,581 & $2 ., 4$ & 509 & 29.9 & 1.00 & & & & & \\
\hline Yes & 3,790 & 70.6 & 1,193 & 70.1 & 1.01 & $0.98-1.03$ & 0.71 & & & \\
\hline \multicolumn{11}{|l|}{$\begin{array}{l}\text { Use of a proton pomp } \\
\text { inhibitor }\end{array}$} \\
\hline No & 1,886 & 35.1 & 628 & 36.9 & 1.00 & & & & & \\
\hline Yes & 3,485 & 64.9 & 1,074 & 63.1 & 1.02 & $0.99-1.05$ & 0.18 & & & \\
\hline \multicolumn{11}{|c|}{$\begin{array}{l}\text { Use of a non-steroidal anti- } \\
\text { inflammatory drug (other } \\
\text { than acetylsalicylic acid) }\end{array}$} \\
\hline No & 4,766 & 88.7 & 1,487 & 87.4 & 1.00 & & & & & \\
\hline Yes & 605 & 11.3 & 215 & 12.6 & 0.97 & $0.93-1.01$ & 0.14 & & & \\
\hline \multicolumn{11}{|c|}{$\begin{array}{l}\text { Total number of different } \\
\text { drugs used }\end{array}$} \\
\hline $1^{\text {st }}$ tertile $(1-9)$ & 1,700 & 31.7 & 501 & 29.4 & 1.00 & & & & & \\
\hline $2^{\text {nd }}$ tertile $(10-15)$ & 1,986 & 37.0 & 644 & 37.8 & 0.98 & $0.95-1.01$ & 0.16 & & & \\
\hline $3^{\text {rd }}$ tertile $(16-50)$ & 1,685 & 31.4 & 557 & 32.7 & 0.97 & 0.94-1.01 & 0.10 & & & \\
\hline
\end{tabular}

